\title{
BUSINESS STRATEGY FORMULATION OF DAYA MINYAK, Ltd
}

\author{
Anugerah Satiawarman, Tanti Sutandra, Ningky Sasanti Munir* \\ Sekolah Tinggi Manajemen PPM Jakarta \\ Correspondence: ningkymunir@gmail.com
}

Submitted: 15 January 2021, Revised: 25 March 2021, Published: 13 April, 2021

\begin{abstract}
The weakening of crude oil price had caused the performance of Daya Minyak, Ltd decline. The efforts to improve had succeeded in improving performance, but it was still below the industry average. Therefore, in 2020 a research was carried out aimed at systematically formulating Daya Minyak, Ltd business strategy for the years 20212024. This applied research was conducted qualitatively, using the business strategy formulation model from David and David (2016) where external strategic issues were compiled in the External Factor Evaluation (EFE) matrix and internal strategic issues in the International Factor Evaluation (IFE) matrix. The weighted value of the EFE matrix is 2.93 and the weighted value of the IFE matrix is 2.97, which meant that the future business strategy is to hold and maintain. Two alternative strategies, market penetration, and product development were developed using the Internal-External (IE) matrix and the TOWS matrix. Two priority strategies, namely a strategy to increase market penetration through integrated services at low costs and a product development strategy through increasing local content with international standards are determined by the Quantitative Strategic Planning Matrix (QSPM).

Keywords: Business Strategy, Hold and maintain, Market Penetration, Product development
\end{abstract}

\section{A. INTRODUCTION}

According to Dahiri (2020) in the analysis of the Bill on the State Budget No. 06 / an.PKA / APBN / IX / 2020 issued by the Budget Study Center for the Expertise Agency of the House of Representatives in 2020, the low decline in world oil prices has been going on since the second semester of 2014. The world oil price continues to show high volatility. In January 2020 world crude oil prices fell, even when compared to December 2019, oil prices experienced the lowest decline in April 2020. Apart from the downward trend and volatility of crude oil prices in the world, since 2014 in Indonesia there has also been a decline in the realization of upstream oil and gas investment (Figure 1).

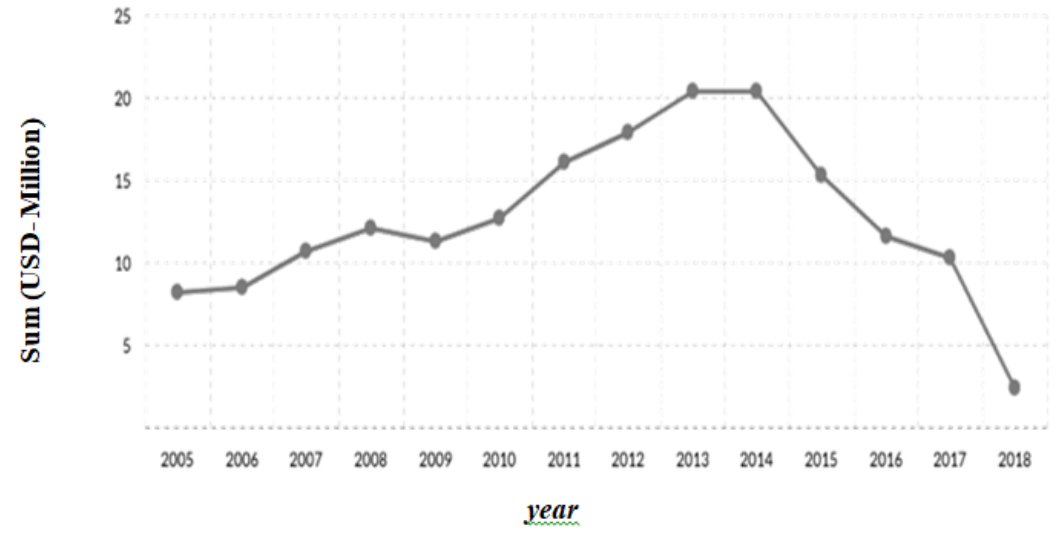

Figure 1. Realization of Upstream Oil and Gas 2005-2018

(Source: https://www.skkmigas.go.id/news ) 
This condition has had an impact on the performance of companies engaged in the oil and gas industry. as that experienced by Daya Minyak, Ltd (not its real name) which is engaged in the service industry well maintenance (well -s services), particularly activities slick-line services, production well testing, heavy-duty fishing services, and bottom hole pressure-temperature service in Indonesia. Revenues Daya Minyak, Ltd from 2014 until 2018 declined about 25\% for almost all of the employer or contractor Contracts (K3S Migas) to renegotiate the price of the rental equipment amounted to 15-30 percent (Figure 2).

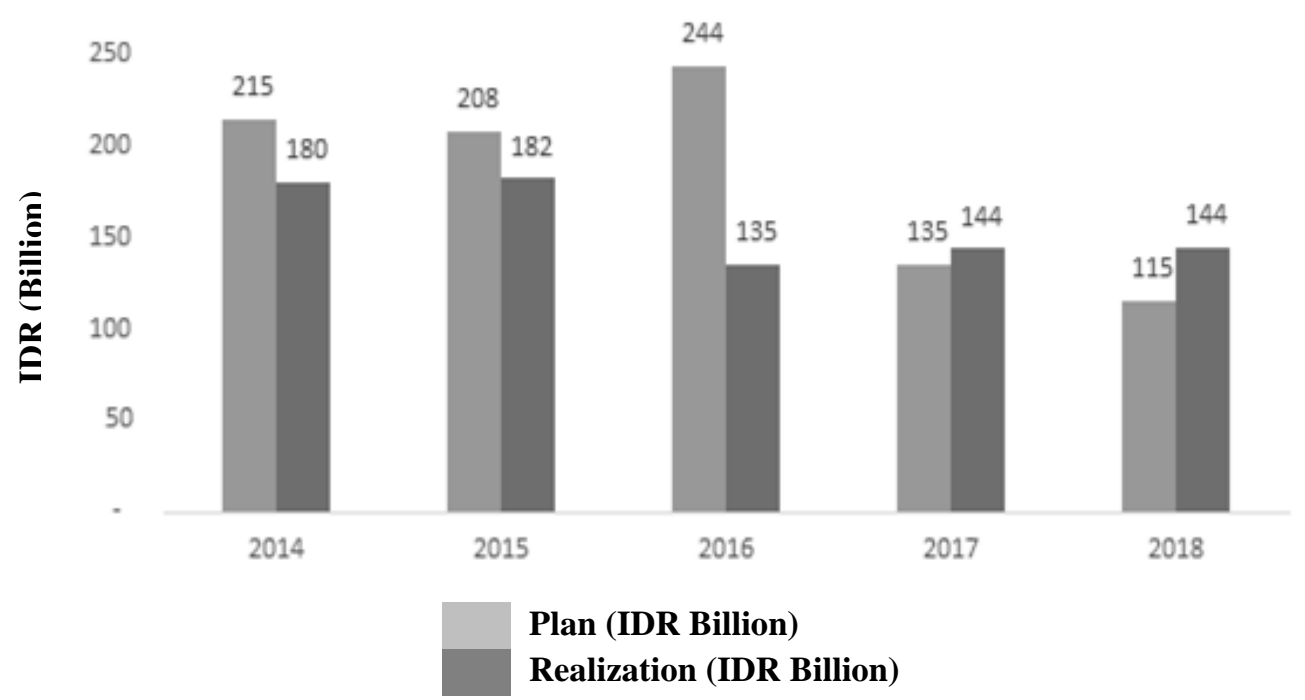

Figure 2. Plan and Realization of Daya Minyak, Ltd Revenue in 2014-2018

(Source: Internal company data processed by the author )

As stated by Fattouh et al. (2017) as well as a recent study by Tonysheva et al. (2019), by increasing pressure from the external environment, companies operating in the oil industry from upstream to downstream need to have a business strategy. With the problems described above, Daya Minyak, Ltd needs to design a business strategy that can guide its executives in dealing with strategic issues that can significantly affect its business performance. the study was conducted with four objectives, namely (1) identify the opportunities and threats that could occur in the business environment of the company, (2) identify the strengths and weaknesses of companies, (3) develop alternative business strategies that may be implemented, and (4) establish the business strategy of Daya Minyak, Ltd for the period 2021-2024. This study is expected to contribute academically to the application of business strategy concepts, particularly the formulation of business strategies in the good care service industry.

\section{B. LITERATURE REVIEW}

The process of compiling a business strategy, according to David and David (201 6 ), consists of three stages, namely strategy formulation, strategy implementation, and evaluation of strategy implementation. This study focuses only on the first phase, namely the formulation of business strategy.

According to David and David (2016) as well as Ayoubi, et al. (2018) the formulation of a business strategy begins with the formulation of a vision and mission first (if not already available). This is important because according 
to Slintak and Dvorsky, (2019) the vision and mission guide the preparation, implementation, and evaluation of the company's business strategy.

Furthermore, the identification of opportunities and external challenges that will be faced by the organization is carried out, as well as identification of the weaknesses and strengths of the organization. The following step is determining strategic objectives following the vision and mission and manufacture of alternative strategies and selection strategies that will apply.

The concept of strategy formulation is in line with Fattouh et al. (2017) and Tony et al. (2019) which describes the development of strategies in the oil and gas service industry. The steps to develop the business strategy are (1) determining targets and objectives; (2) evaluating the macro environment; (3) evaluate the company's internal potential; (4) competitive analysis of oilfield services companies; and (5) create a development strategy using a matrix model that fits the company's goals.

In formulating a strategy, it is necessary to have an external analysis that identifies and evaluates trends and events beyond the company's control. Singh and Srivastava (2019), and Serfointein and Govender (2020) explain that the PEST EL analysis (Politics, Economics, Social, Technology, Environment, Legal) is a framework for assessing the situation, strategy, position, direction, marketing plan, or company idea can assist and direct the direction of strategies according to current and future developments.

Like PESTEL's analysis, Porter's Five Forces Analysis is a framework that can be used to analyze the level of competition in the development of industrial and business strategy levels, what distinguishes the two analyzes is taking a perspective from the industrial sector of the company (Porter, 1998 ). In industry analysis, an analysis of five competitive forces, the bargaining power of customers, bargaining power of suppliers, the intensity of competition, the threat of new entrants, and substitute products.

The results of the external analysis are opportunities and threats, including in a matrix that is the matrix External Factors Evaluation (EFE). According to David and David (201 6 ), the EFE matrix will help the strategists at the business level to gain an overview of how conducive the environment in which it operates and the companies to respond to opportunities and threats in the external environment.

Coman and Ronen (2009) and David and David (201 6 ) reveal that the readiness and viability of companies that compete with their competitors are strongly influenced by the strengths and weaknesses of the company itself because strengths will provide advantages while weaknesses will provide weaknesses. Analysis to identify strengths and weaknesses is functional analysis. Furthermore, according to David and David (2016), the results of the internal environmental analysis are then compiled into a matrix called the Internal Factors Evaluation (IFE) matrix. The IFE matrix shows the internal factors that are the major and minor strengths, as well as the company's major and minor weaknesses.

After analyzing the external and internal environment, the results of the EFE and IFE analysis are matched using the Internal External Matrix (IE) to obtain the main strategy to be developed. The analysis phase of the Internal External Matrix (IE) is carried out by entering the parameters used by the internal and external forces originating from the EFE Matrix on the Y-axis and the IFE Matrix on the $\mathrm{X}$-axis which will give a result at the intersection of $\mathrm{X}$ and $\mathrm{Y}$ (Figure 3 ). 
Internal Factor Evaluation

\begin{tabular}{|c|c|c|}
\hline $\begin{array}{c}\text { I } \\
\text { Grow \& Build }\end{array}$ & $\begin{array}{c}\text { II } \\
\text { Grow \& Build }\end{array}$ & Hold \& Maintain \\
\hline $\begin{array}{c}\text { IV } \\
\text { Grow \& Build }\end{array}$ & Hold \& Maintain & Harvest Or Divest \\
\hline $\begin{array}{c}\text { VII } \\
\text { Hold \& Maintain }\end{array}$ & Harvest Or Divest & Harvest Or Divest \\
\hline
\end{tabular}

Figure 3. Internal-External Matrix (IE)

(Source: David and David, 2016)

Based on the results of the internal-external matrix (IE), a SWOT analysis (Strengths, Weaknesses, Opportunities, Threats) was carried out with the help of the TOWS matrix to formulate alternative strategies by combining internal and external factor evaluation with the main strategies that have been obtained (Helms and Nixon, 2010; Abbasi, et al ., 2019; Vlados, 2019).

According to Pazouki, et al. (2017), David and David (2016), and reinforced by Abbasi, et al. (2019) companies need to determine priority strategies that will be implemented immediately. David and David (2018) developed the Quantitative Strategic Priority Matrix ( QSPM ) analysis tool, which is an analytical tool that allows decision-makers to evaluate alternative strategies objectively, based on key factors both from the external environment (EFE matrix) and internally (IFE matrix). ) that have been identified previously. According to Pazouki, et al. (2017) and Abbasi, et al. (2019) conceptually QSPM is a very common technique and method in evaluating strategic options and determining the relative attractiveness of strategies; the attractiveness of the strategy is used in the decision-making stage. This technique determines which of the selected strategic options is feasible, and it prioritizes this strategy ( Abbasi, et al., 2019).

\section{RESEARCH METHOD}

This research is applied research. The aim of applied research by Sekaran and Bougie (2016), among others: (1) improving the understanding of specific business or management problems; (2) solve the problem; (3) raises new knowledge on a limited problem; and (4) find practical relevance and value for managers within the firm. The research process in this study uses a descriptive research method, which is a method that focuses on problem-solving by trying to understand and analyze a phenomenon and the actual problem that is being faced and trying to find a clearer solution and understanding of an event or problem (Sekaran and Bougie, 2016). ).

Primary data were obtained through interviews with the directors of Daya Minyak, Ltd and interviews with functional managers (HR, operations, and finance). Secondary data, especially those related to external analysis are obtained through the SKK Migas Annual Report, Energy Outlook from the IOG (Independent Oil and Gas) and IEA (International Energy Agency), the website of the Delloite 
consultancy agency that discusses ER and I (Energy, Resources, and Industrials). ), and various websites containing Indonesia's economic outlook.

\section{ANALYSIS AND DISCUSSION}

To make use of $\mathrm{n}$ tool PESTEL analysis, researchers together with the Board of Directors and senior manager at Daya Minyak, Ltd identifying the opportunities and four threats. From political and legal factors, the new gross split regulation in 2020 could be an obstacle to industrial expansion. Because the cost recovery scheme is no longer applied to several oil and gas blocks, upstream oil and gas companies will be more careful if they want to start a project. Well-services activities could result in millions of dollars in losses for upstream oil and gas companies. Therefore a more mature calculation is needed to be able to maximize the return (return) of exploration and exploitation projects. This regulation will have an impact on oil and gas service companies in the year 2021 because many oil and gas companies have expired their contracts and the government recommends using a gross split scheme if the management period continues.

For conditions abroad, with the impact of the oil war between OPEC countries not OPEC and excess production of crude oil even though it has been agreed to limit oil production of 9.7 million bbl (Blue Barrel; unit price of crude oil), this may not be profitable for the industry. oil and gas because it resulted in a very sharp decline in crude oil prices and created conditions that were far worse than in previous years. This condition is a threat to oil and gas service companies because many oil and gas companies have postponed their projects.

From an economic perspective, the impact of the Covid-19 pandemic and the instability of global crude oil prices made oil and gas companies in the world postpone exploration and exploitation of new oil fields. This has resulted in a decrease in the attractiveness of the upstream oil and gas industry. Considering the fall in crude oil prices in the last five years, many oil and gas companies in Indonesia are trying to reduce the amount of investment and reduce operating expenses by 30 percent of the approved budget.

On the other hand, the government-mandated all upstream oil and gas company to be able to maintain the level of production, or at least maintain the rate of decline in the trend of leaner. Thus, rework activities or well maintenance can still be carried out during the pandemic period. Rework and well maintenance activities will continue to be increased until the price of oil returns to normal, then the search for and development of new land will then be resumed.

Currently, the government continues to make efforts to prevent foreign oil and gas investors from leaving Indonesia, one of which is by eliminating the branch profit tax of 20 percent. With the hope, when Indonesia's economic prospects have improved and future energy demand has increased, there will be many oil and gas projects that can be mobilized to seize upstream oil and gas opportunities in Indonesia.

From a socio-cultural perspective, the growth rate of urban people and demographic growth in Indonesia will increase energy demand, thereby increasing the search for and developing oil and gas fields. This makes well service activities an option for increasing oil and gas production.

From an environmental perspective, as a country that has the complexity of the basin as a source of oil and gas, currently, many oil fields are old and naturally unproductive. This is an opportunity for well services companies to remove trapped oil 
resources by optimizing oil production using the EOR (Enhanced Oil Recovery) method.

Industry analysis was carried out using Porter's (1998) Five Competitive Strengths analysis tool. Researchers with the Board of Directors and senior managers of Daya Minyak, Ltd to determine the pressures of the five competitive forces to determine the attractiveness of the industry as well as the opportunities and threats of the good services industry. In Indonesia, as a whole, the oil and gas industry (oil and gas) has a very large business opportunity, with large project values and attractive margins, so that the level of competition in this industry is quite high. Medium-sized local companies such as Daya Minyak, Ltd or PT. Prowell Energy Indonesia must compete with multinational companies such as Schlumberger, Halliburton, and Expro Indonesia, as well as the company's Board of State-owned Enterprise (SOE) such as PT. Elnusa, Tbk. which has a similar line of business with a business scale that is very different from the local company.

Most of these large multinational companies have high service standards and can provide similar services satisfactorily. When compared with local companies, offering more competitive prices and good service standards can help maintain the business potential of local companies. With the number of players in the same field that are not many, the intensity of competition is not too high (medium).

Industri well services have to obstacle enters the lucrative and powerful, namely: (1) certain capital investment requirements to provide equipment slick-line units, data acquisition, and special tools; (2) relatively high working capital requirements to carry out well maintenance work, must bear operational costs while waiting for payment from clients; (3) certain qualification and experience level requirements to do well maintenance work; and (4) brand loyalty and trust. This makes the threat of newcomers very low.

The slick-line unit equipment owned by the company must be able to compete with electric line unit equipment that has the same function as more sophisticated technology or coiled tubing that is capable of working in high deviated wells. However, this sophisticated equipment is not a serious threat during uncertain oil prices, oil and gas companies take advantage of the use of slick-line units in well maintenance work because the costs are much more competitive when compared to electric line or coiled tubing so that the threat of replacement products can be said. low.

In terms of the bargaining power of buyers, according to the guidelines for procurement of SKK Migas PTK 007, the upstream oil and gas companies are endeavored to make a tender for the procurement of well maintenance service contracts. If a tender cannot be carried out, then it is permitted to make a direct appointment to a good services company as long as the terms and conditions are in line with the procurement guidelines. On the other hand, oil and gas companies can renegotiate the contract value of well service companies in the event of a decline in world oil prices. This makes upstream oil and gas companies quite sensitive to the contract value so that the bargaining power of buyers is currently high. With a production target of 1 million bbl for 2024 and the limitations of well service companies in Indonesia, the bargaining power of buyers in the future will be reduced to moderate.

Finally, in terms of the bargaining power of suppliers, consumables for good maintenance activities are widely available at relatively favorable bidding prices so that the bargaining power of suppliers is relatively small. Currently, the procurement of slick-line unit supporting equipment that has special specifications, such as 
data acquisition tools, pressure control equipment, and blow-out preventer, is still not common on the market and has high bargaining power. However, in the future, the need for special specifications and quality equipment can be supplied from China with quite a lot of supply options. Thus the bargaining power of suppliers can currently be categorized as moderate, while for 2024 it is categorized as low with the assumption that the Covid-19 pandemic ends and global economic conditions return to normal.

Opportunities and threats of the external environment of macro and industry environment and the quality of response strategic company in the matrix EFE compiled in Table 1. The weighted value of $\mathbf{2 . 9 3}$ means that Daya Minyak, Ltd well maintenance service business is running well, can take advantage of external opportunities, and minimize potential damaging impacts from external threats. Opportunities with relatively high weights are loyalty to the brand $(\mathrm{O} 8)$ which weights 0,071 with a value of 4 because the company has a good relationship with some oil and gas companies, providing a cheaper price than its competitors and brand image that is strong enough.

To overcome threat competition with ten competitors (T5) whose weight is high, the company must continue to promote good relations with oil and gas companies, improve the quality and Human resource (SDM). The threat other with high weights is a supplier of equipment (T7), rating the company is 3 because the company can look for other products to reduce dependence on any one supplier.

Table 1. EFE Daya Minyak, Ltd Matrix

\begin{tabular}{|c|c|c|c|c|c|c|}
\hline No. & External Factors & Code & $\begin{array}{l}\text { Weight } \\
\text { (B) }\end{array}$ & $\begin{array}{l}\text { Score } \\
(\mathbf{N})\end{array}$ & $\begin{array}{c}\mathbf{B} \mathbf{x} \\
\mathbf{N}\end{array}$ & Value Description \\
\hline \multicolumn{7}{|c|}{ Opportunities (Opportunities) } \\
\hline 1 & $\begin{array}{lr}\text { The } & \text { government } \\
\text { continues } & \text { to } \\
\text { domestic } & \text { ointain } \\
\text { production } & \end{array}$ & O1 & 0.060 & 3 & 0.18 & $\begin{array}{l}\text { The company has a large market } \\
\text { share in a certain area and can make } \\
\text { its tools }\end{array}$ \\
\hline 2 & $\begin{array}{l}\text { The projection of } \\
\text { economic growth in } \\
\text { the next four years } \\
\text { despite the pandemic }\end{array}$ & $\mathrm{O} 2$ & 0.050 & 3 & 0.15 & $\begin{array}{l}\text { In the last five years, the company } \\
\text { was able to win the good } \\
\text { services project tender due to its } \\
\text { good reputation }\end{array}$ \\
\hline 3 & $\begin{array}{lr}\text { Delays in exploration } \\
\text { and development } \\
\text { projects }\end{array}$ & $\mathrm{O} 3$ & 0.060 & 3 & 0.18 & $\begin{array}{l}\text { Companies can work on projects } \\
\text { more efficiently }\end{array}$ \\
\hline 4 & $\begin{array}{l}\text { Projected increase in } \\
\text { demand for BBM }\end{array}$ & $\mathrm{O} 4$ & 0.055 & 3 & 0.16 & $\begin{array}{l}\text { In the last five years, the company } \\
\text { was able to win the good } \\
\text { services project tender due to its } \\
\text { good reputation }\end{array}$ \\
\hline 5 & $\begin{array}{l}\text { Projected increase in } \\
\text { energy demand }\end{array}$ & O5 & 0.062 & 3 & 0.19 & $\begin{array}{l}\text { In the last five years, the company } \\
\text { was able to win the good } \\
\text { services project tender due to its } \\
\text { good reputation }\end{array}$ \\
\hline 6 & $\begin{array}{l}\text { The tendency to } \\
\text { optimize old oil fields }\end{array}$ & O6 & 0.067 & 3 & 0.20 & $\begin{array}{l}\text { Companies can work on projects } \\
\text { more efficiently }\end{array}$ \\
\hline 7 & $\begin{array}{l}\text { Large working capital } \\
\text { requirements }\end{array}$ & $\mathrm{O} 7$ & 0.069 & 3 & 0.21 & $\begin{array}{l}\text { The company has strong financial } \\
\text { capabilities }\end{array}$ \\
\hline 8 & $\begin{array}{l}\text { Brand loyalty due to } \\
\text { the reputation of the } \\
\text { work }\end{array}$ & $\mathrm{O} 8$ & 0.071 & 4 & 0.29 & $\begin{array}{l}\text { In the last five years, the company } \\
\text { was able to win the good } \\
\text { services project tender due to its } \\
\text { good reputation }\end{array}$ \\
\hline
\end{tabular}


Threats

\begin{tabular}{|c|c|c|c|c|c|c|}
\hline No. & External Factors & Code & $\begin{array}{l}\text { Weight } \\
\text { (B) }\end{array}$ & $\begin{array}{l}\text { Score } \\
(\mathbf{N})\end{array}$ & $\begin{array}{ll}\mathbf{B} & \mathbf{x} \\
\mathbf{N} & \end{array}$ & Value Description \\
\hline 9 & $\begin{array}{l}\text { The existence of } \\
\text { regulations } \\
\text { regarding gross-splits }\end{array}$ & $\mathrm{T} 1$ & 0.064 & 3 & 0.19 & $\begin{array}{l}\text { The company can maintain good } \\
\text { relations with oil and gas companies } \\
\text { that have carried out gross- } \\
\text { splits without reducing the quality } \\
\text { of work }\end{array}$ \\
\hline 10 & $\begin{array}{l}\text { There is an oil- } \\
\text { war between the } \\
\text { world's oil-producing } \\
\text { countries }\end{array}$ & $\mathrm{T} 2$ & 0.067 & 2 & 0.13 & $\begin{array}{l}\text { Companies can carry out internal } \\
\text { efficiency without sacrificing } \\
\text { quality }\end{array}$ \\
\hline 11 & $\begin{array}{l}\text { The Covid } 19 \\
\text { pandemic continues }\end{array}$ & T3 & 0.074 & 2 & 0.15 & $\begin{array}{l}\text { The company can perform work } \\
\text { with strict health protocols and high } \\
\text { standards }\end{array}$ \\
\hline 12 & $\begin{array}{l}\text { Projected decline in } \\
\text { crude oil prices }\end{array}$ & $\mathrm{T} 4$ & 0.069 & 3 & 0.21 & $\begin{array}{l}\text { Companies can carry out internal } \\
\text { efficiency } \\
\text { quality }\end{array}$ \\
\hline 13 & $\begin{array}{l}\text { The intensity of } \\
\text { competition for similar } \\
\text { companies in the } \\
\text { industry }\end{array}$ & T5 & 0.079 & 3 & 0.24 & $\begin{array}{l}\text { In the last five years, the company } \\
\text { was able to win the good } \\
\text { services project tender due to its } \\
\text { good reputation }\end{array}$ \\
\hline 14 & $\begin{array}{l}\text { Increase in the effect } \\
\text { of oil prices on the } \\
\text { contract value }\end{array}$ & T6 & 0.076 & 3 & 0.23 & $\begin{array}{l}\text { Companies can work on projects } \\
\text { more efficiently }\end{array}$ \\
\hline 15 & $\begin{array}{l}\text { Limitations of tool } \\
\text { suppliers }\end{array}$ & $\mathrm{T} 7$ & 0.079 & 3 & 0.24 & $\begin{array}{l}\text { The company can make its tools and } \\
\text { has an alternative supplier of tools }\end{array}$ \\
\hline & Total & & 1 & & 2.93 & \\
\hline
\end{tabular}

To identify strengths and weaknesses in the company's internal environment, researchers discuss it with senior managers who have authority in each function. The results of the discussion were then presented to the Directors of Daya Minyak, Ltd to enrich the results of the analysis.

From the Human Resource (HR) function, currently, all HR functions are carried out centrally, with the head office carrying out its functions starting from the recruitment process to termination of employment. Even though the company has employees who are capable of carrying out HR functions, there is no career development plan for all employees, it is evident that the training program provided is only limited to obligations that must be fulfilled following the training needs contained in the contract with the customer. Since its establishment, the company has not conducted structured, reliable, and fair performance appraisals for employees. Assessment is only carried out by superiors, it is one way without any clear feedback. Besides, the structure of remuneration is unclear because salary increases, bonuses, or incentives are not made annually and are only given at the discretion of the director. However, the company still meets the remuneration standard as stipulated in the Minister of Manpower Regulation, and to date, the company has never done any layoffs (Termination of Employment) even though it is experiencing an economic crisis.

The level turnover for each business unit is not too great, as in the unit slickline unit services as the largest revenue contributor has a level of turnover on average 2 percent in the last five years. This shows that the level of employee loyalty in the company is quite high. Based on the results of a survey of 50 employees, 50 percent of the respondents have worked for more than 10 years. From existing searches, many 
employees feel comfortable working in the company because the regulations are not too strict and the company tolerates very high employees.

This leeway is used by manufacturing workers to find additional income utilizing over time, tends to procrastinate work, and the habit of arriving late to the office. This habit has become a culture that is very detrimental to the company and it is necessary to transform the work culture. On the other hand, the company has many wireline specialists who are loyal, highly competent, and internationally certified. The loyalty of a wireline specialist is very rarely found in similar companies in the good services industry in Indonesia.

To function marketing, companies do not dedicate divisions or departments or commercial marketing specifically to formulate the appropriate marketing program in support of the target company. As a substitute, the company has an Operation Account Representative for each oil and gas company who is given additional tasks like marketing, even though the person concerned does not have sufficient marketing knowledge. The company can offer a more competitive price compared to other competitors with the same technical specifications. The lower price is because the company can make well services equipment and other supporting tools so that the local content of the content is more than 80 percent. Compared with other competitors who still import from abroad.

Currently, most of the projects are obtained due to the trust and good relationship between customers and the Board of Directors, although they still go through a tender process or direct appointment. For the future, if the current directors are no longer involved and if there is still no division of work, especially in terms of formulating and implementing marketing strategies, then a decline in company performance will likely occur. The company still has not made long-term planning and marketing planning. Currently, the annual target is only formulated by the director and finance manager and has never been conveyed to other managers. This results in the absence of clear directions in achieving company goals or targets.

The company's current brand image is quite strong in the oil and gas industry in Indonesia. Daya Minyak, Ltd is the first local oil and gas service company to dare to invest in a good maintenance project in the Mahakam river area using a vessel in 2003 and currently, seven slickline unit package vessels are operating in the area. As a result, the company was able to build strong relationships with several oil and gas companies in Indonesia.

For the operation function, most of the company's assets have not been fully utilized, for example, the oil and gas production testing equipment (well testing) which has never contributed to revenue in the last five years. Likewise, the data acquisition unit only relies on contracts with slick-line unit services. This condition occurs due to a lack of planning and marketing strategies in each business unit so that the company's assets have not been optimized to maximize value for shareholders.

Over the years, the company has succeeded in maintaining the quality and efficiency of work to customers, it has been proven that the company has been able to reduce the failure rate of operations below 3 percent in the last five years, and is consistent with K3L regulations by showing the results of no fatality or loss of work time within a period. Daya Minyak, Ltd has always been committed to providing new, quality, and internationally certified equipment following customer demands. Through operational optimization, companies can still increase revenue and profits.

The customer satisfaction survey that was conducted by PT Power of Oil in 2018 and 2019 showed that customers are satisfied with the performance of the company in 
support of operations in the upstream oil and gas during this time. Another thing that is rarely shared by other similar companies in the spirit possessed by the operations team, namely never giving up in facing problems (giving up is unlawful) in the field, this shows the dedication of field employees to the company.

The evaluation of the production function shows that to support the continuity of operations in the field, the company has a workshop as a manufacturing facility for equipment such as slick-line units, powerpack generators, and specialty tools needed for these operational activities. Not all similar companies have the facilities to build this equipment.

There is still a large amount of material waste in workshop activities and there is a tendency for the equipment production process to still not meet the needs and standards set by customers, resulting in the equipment that has been made instead of being waste because of this stock inventory cannot be used. This can be avoided or minimized if the workshop manager and his subordinates better understand and understand proper production and inventory management. Some errors in the manufacture of equipment/units were caused by the absence of coordination with the tender or contract holder part and prefer the assumptions in the construction according to the specifications in the previous year, the information requirements that are not detailed tool-making and lack of quality control that is true.

For financial functions, the company has very low solvency or leverage compared to similar companies. Thus, the company has more room to increase its capital investment by raising funds from commercial loans. The ease of providing capital provided by banks is a very profitable value for the company. The company is capable of managing assets and shareholder capital to generate profits, with a ROA (Return on Assets) of 6 percent and an ROE (Return on Equity) of 7 percent, above the industry average of 0.19 percent. Even so, the company does not yet have a good asset management system, as evidenced by the fact that in 2016 there was an imposition of asset depreciation value that was not taken into account the previous two years.

For internal analysis, power and Ex e Mahan companies compiled in IFE matrix (Table 3). Based on Table 2, the weighted score of $\mathbf{2 . 9 7}$ means that Daya Minyak, Ltd has an internal position slightly above the 2.5 average. This shows that the company is still able to take advantage of its strengths and can overcome existing weaknesses.

The main strengths of this company are competitive prices, good company relations, and brand image which has a weight of 0.088 and a weighted score of 0.35 which means that the most influential internal factors, the company can respond well, namely by having good cooperation that can foster trust and provide a lower price than its competitors.

Other influential strengths are the expertise of internationally certified field staff, fairly high employee loyalty, Health Safety Environment (HSE) performance record, integration of operations and experience, quality of products and services, and a strong financial position.

However, the company has a weakness with a rating of 2 in production and material management, corporate governance and assets and performance appraisals, which means that the company still can be able to manage production and materials through personal placement and replacement of competent QA / QC departments, apart from that Daya Minyak, Ltd can regulate corporate governance by referring to Law No. 40 of 2007, while for the performance appraisal of company employees still can assess employees even though it is still a one-way assessment. 
Based on the results of the Total IFE Score of 2.97 and the Total EFE Score of 2.93, the position of Daya Minyak, Ltd in the IE matrix is in cell V $(2.97 ; 2.93)$. Cell V shows the area where the company's overall condition is considered moderate. According to David and David (2016), s Strategy right company for companies that are in the cell $\mathrm{V}$ is resistant and maintain ( hold and maintain ), with two options, namely a strategy of market penetration and product development.

Table 2 . Daya Minyak, Ltd IFE Matrix

\begin{tabular}{|c|c|c|c|c|c|}
\hline No. & Internal Factors & Code & $\begin{array}{l}\text { Weight } \\
\text { (B) }\end{array}$ & $\begin{array}{l}\text { Score } \\
(\mathbf{N})\end{array}$ & $\mathbf{B} \times \mathbf{N}$ \\
\hline \multicolumn{6}{|c|}{$\begin{array}{ll}\text { Strength (Strength) } \\
\end{array}$} \\
\hline 1 & Employees are highly skilled, have international certifications & S1 & 0.082 & 3 & 0.25 \\
\hline 2 & Employees have high loyalty, the average turnover rate is $2 \%$ & $\mathrm{~S} 2$ & 0.082 & 3 & 0.25 \\
\hline 3 & Have a good relationship with customers & S3 & 0.088 & 4 & 0.35 \\
\hline 4 & Competitive price compared to competitors & S4 & 0.088 & 4 & 0.35 \\
\hline 5 & Strong brand image & S5 & 0.088 & 4 & 0.35 \\
\hline 6 & High quality work & S6 & 0.071 & 3 & 0.21 \\
\hline 7 & HSE (Health Safety Environment) performance is very good & S7 & 0.071 & 3 & 0.21 \\
\hline 8 & Ability to integrate project operations with good experience & S8 & 0.071 & 3 & 0.21 \\
\hline 9 & Have financial strength & S9 & 0.066 & 3 & 0.20 \\
\hline \multicolumn{6}{|c|}{ Weakness } \\
\hline 10 & $\begin{array}{l}\text { Systematic employee performance appraisal has not been } \\
\text { fully implemented }\end{array}$ & W1 & 0.052 & 2 & 0.10 \\
\hline 11 & $\begin{array}{l}\text { Corporate governance assessments have not been carried out } \\
\text { routinely }\end{array}$ & W2 & 0.060 & 2 & 0.12 \\
\hline 12 & $\begin{array}{l}\text { The company's targets and strategies have not been well } \\
\text { communicated to executive employees }\end{array}$ & W3 & 0.049 & 2 & 0.10 \\
\hline 13 & Sometimes project material management does not go well & W4 & 0.069 & 2 & 0.14 \\
\hline \multirow[t]{2}{*}{14} & $\begin{array}{l}\text { Corporate asset governance has not been carried out in a } \\
\text { structured manner }\end{array}$ & W5 & 0.060 & 2 & 0.12 \\
\hline & Total & & 1 & & 2.97 \\
\hline
\end{tabular}

The development of alternative strategies uses the TOWS matrix, as shown in Table 3. The results of the SWOT analysis are shown in the TOWS matrix, the details of the market penetration strategy are as follows:

1. Increase marketing capabilities to attract new customers to increase the company's market share in the oil and gas industry;

2. Retain existing customers by improving service and providing price flexibility.

3. Increase market penetration and development through integration by utilizing business lines to provide total solutions to clients. This strategy can take full advantage of resources and offer comprehensive good care services by bringing together various expertise in one contract package.

4. Improve company performance management to increase the achievement of company targets. This strategy is expected to improve the company's performance in managing existing resources.

5. Increase the ability to market a product or well maintenance support tool. This strategy is needed to deal with competitors who have better abilities in marketing.

6. Performing strategies at low costs during operations and production to survive in uncertain situations. This strategy is needed so that the company can continue to compete even in uncertain situations and can still capture business opportunities from other oil and gas companies. 
Table 3. Daya Minyak, Ltd TOWS Matrix

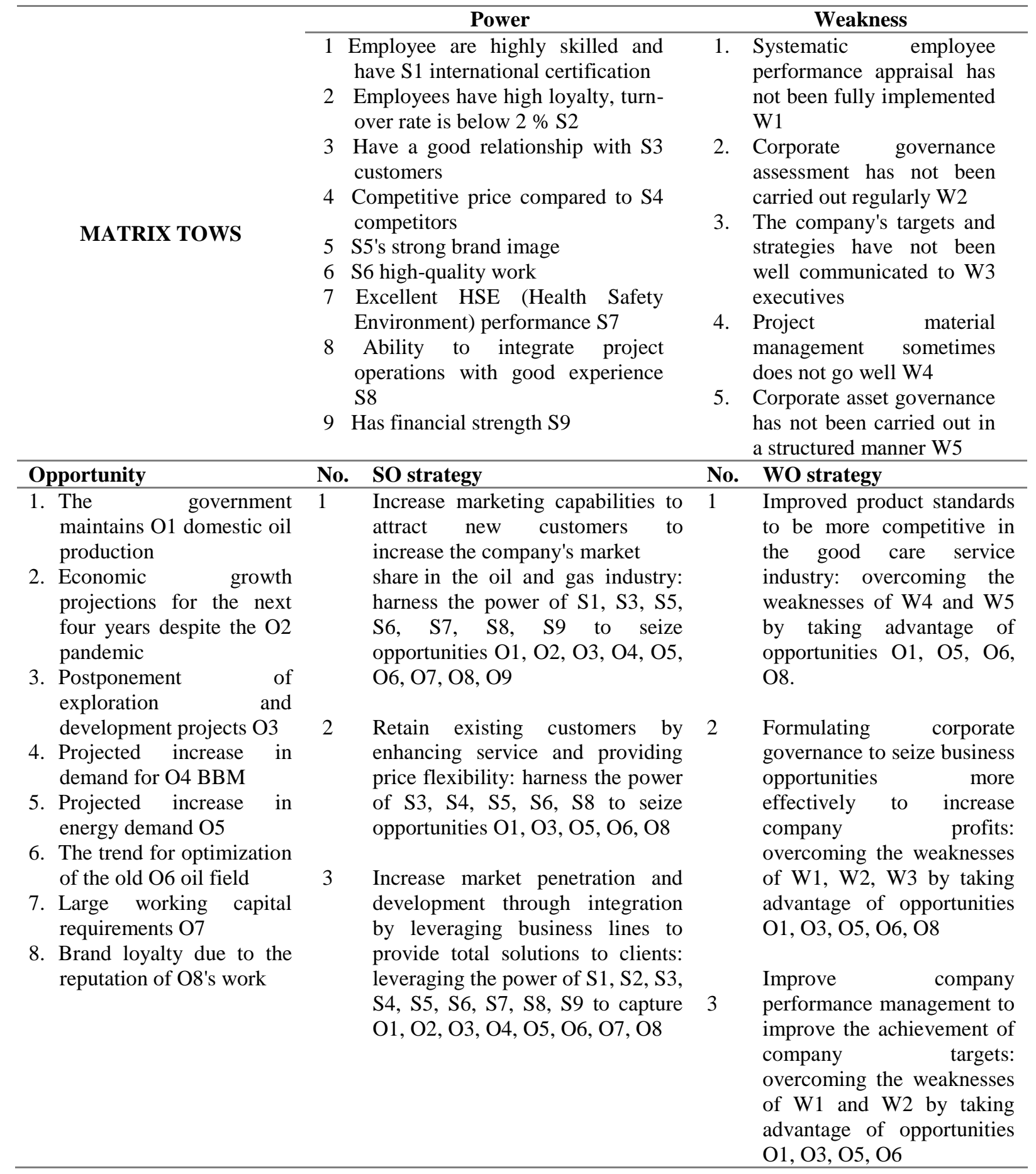


Continued Table 3

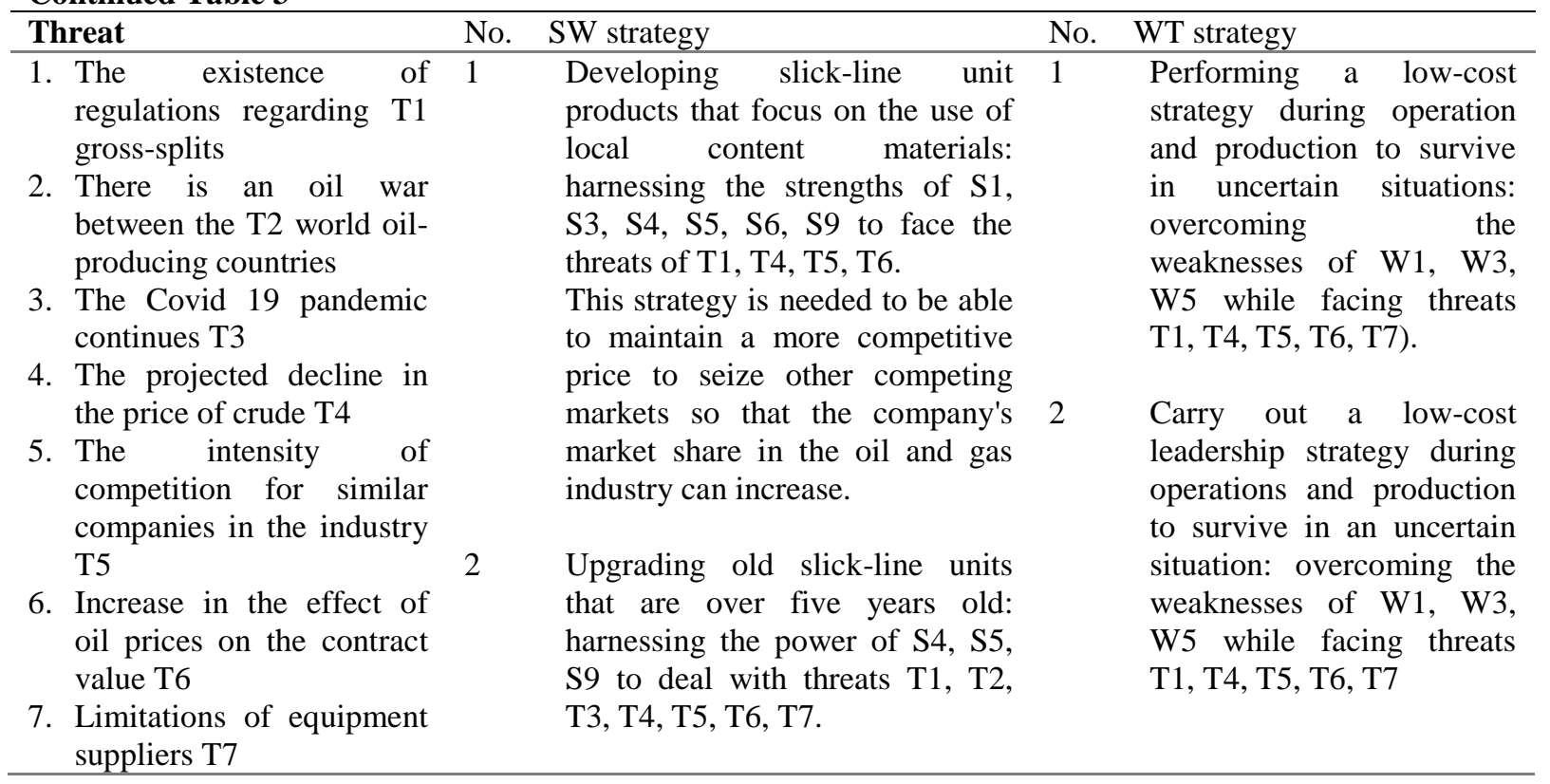

For the product development strategy, the details are as follows:

1. Developing a slick-line unit product that focuses on the use of local content material. This strategy is needed to be able to maintain a more competitive price to seize other competing markets so that the company's market share in the oil and gas industry can increase.

2. Perform renewal of old slick-line units that are more than five years old.

3. Increased product standards to be more competitive in the good care service industry.

From several strategies for market penetration and product development, two alternative strategies can be summarized, namely:

1. Increase market penetration through integrated services with low operating costs.

2. Developing products through increasing local material content with international standards.

Furthermore, to determine the priority strategy, a Quantitative Strategic Planning Matrix (QSPM) analysis is performed. Following the QSPM analysis in Table 4, the highest total score of attractiveness is $\mathbf{4 . 7 8 7}$, namely the alternative strategy "Increasing market penetration through integrated services with low operating costs". This strategy excels in seizing opportunities by relying on strength. Meanwhile, the alternative strategy "Developing products through increasing local material content with international standards" has a total attractive score of $\mathbf{4 . 4 2 6}$, especially for overcoming company weaknesses. 
Table 4. Quantitative Strategic Planning Matrix (QSPM)

\begin{tabular}{|c|c|c|c|c|c|c|}
\hline \multirow[b]{2}{*}{ No. } & \multirow[b]{2}{*}{ Factor } & \multirow[b]{2}{*}{ Weight } & \multicolumn{2}{|c|}{$\begin{array}{c}\text { Strategy } 1 \\
\text { Market penetration }\end{array}$} & \multicolumn{2}{|c|}{$\begin{array}{c}\text { Strategy } 2 \\
\text { Product Development }\end{array}$} \\
\hline & & & US & BAG & $\mathbf{U S}$ & BAG \\
\hline \multicolumn{7}{|c|}{ Opportunity } \\
\hline 1 & $\begin{array}{l}\text { The government continues to } \\
\text { maintain domestic oil production }\end{array}$ & 0.060 & 4 & 0.238 & 3 & 0.179 \\
\hline 2 & $\begin{array}{l}\text { The projection of economic growth } \\
\text { in the next four years despite the } \\
\text { pandemic }\end{array}$ & 0.050 & 4 & 0.200 & 3 & 0.150 \\
\hline 3 & $\begin{array}{l}\text { Delays in exploration and } \\
\text { development projects }\end{array}$ & 0.060 & 2 & 0.119 & 1 & 0.060 \\
\hline 4 & $\begin{array}{l}\text { Projected increase in demand for } \\
\text { BBM }\end{array}$ & 0.055 & - & - & - & - \\
\hline 5 & $\begin{array}{l}\text { Projected increase in energy } \\
\text { demand }\end{array}$ & 0.062 & 3 & 0.186 & 2 & 0.124 \\
\hline 6 & $\begin{array}{l}\text { The tendency to optimize old oil } \\
\text { fields }\end{array}$ & 0.067 & 4 & 0.267 & 3 & 0.200 \\
\hline 7 & Large working capital requirements & 0.069 & - & - & - & - \\
\hline 8 & $\begin{array}{l}\text { Brand loyalty due to the reputation } \\
\text { of the work }\end{array}$ & 0.071 & 4 & 0.286 & 3 & 0.214 \\
\hline \multicolumn{7}{|c|}{ Threat } \\
\hline 9 & $\begin{array}{l}\text { The existence of regulations } \\
\text { regarding gross-splits }\end{array}$ & 0.064 & 3 & 0.193 & 4 & 0.257 \\
\hline 10 & $\begin{array}{l}\text { There is an oil-war between the } \\
\text { world's oil-producing countries }\end{array}$ & 0.067 & - & - & - & - \\
\hline 11 & The Covid 19 pandemic continues & 0.074 & 2 & 0.148 & 1 & 0.074 \\
\hline 12 & Projected decline in crude oil prices & 0.069 & 2 & 0.138 & 1 & 0.069 \\
\hline 13 & $\begin{array}{l}\text { The intensity of competition for } \\
\text { similar companies in the industry }\end{array}$ & 0.079 & 3 & 0.236 & 4 & 0.314 \\
\hline 14 & $\begin{array}{l}\text { Increase in the effect of oil prices } \\
\text { on the contract value }\end{array}$ & 0.076 & 2 & 0.152 & 3 & 0.229 \\
\hline 15 & Limitations of tool suppliers & 0.079 & 3 & 0.236 & 2 & 0.157 \\
\hline \multicolumn{7}{|c|}{ Power } \\
\hline 16 & $\begin{array}{l}\text { The employees are highly skilled } \\
\text { and have international certifications }\end{array}$ & 0.082 & 3 & 0.246 & 4 & 0.328 \\
\hline 17 & $\begin{array}{l}\text { Employees have high loyalty, turn- } \\
\text { over rate is below } 3 \%\end{array}$ & 0.082 & - & - & - & - \\
\hline 18 & $\begin{array}{l}\text { Have a good relationship with } \\
\text { customers }\end{array}$ & 0.088 & 4 & 0.352 & 3 & 0.264 \\
\hline 19 & $\begin{array}{l}\text { Competitive price compared to } \\
\text { competitors }\end{array}$ & 0.088 & 3 & 0.264 & 4 & 0.352 \\
\hline 20 & Strong brand image & 0.088 & 4 & 0.213 & 3 & 0.264 \\
\hline 21 & High quality work & 0.071 & 3 & & 4 & 0.284 \\
\hline 22 & $\begin{array}{l}\text { HSE (Health Safety Environment) } \\
\text { performance is very good }\end{array}$ & 0.071 & - & - & - & - \\
\hline 23 & $\begin{array}{l}\text { Ability to integrate project } \\
\text { operations with good experience }\end{array}$ & 0.071 & 3 & 0.213 & 2 & 0.142 \\
\hline 24 & Have financial strength & 0.066 & 4 & 0.264 & 3 & 0.198 \\
\hline
\end{tabular}




\begin{tabular}{|c|c|c|c|c|c|c|}
\hline \multicolumn{7}{|c|}{ Continued Table 4} \\
\hline \multicolumn{7}{|c|}{ Weakness } \\
\hline 25 & $\begin{array}{l}\text { Systematic employee performance } \\
\text { appraisal has not been fully } \\
\text { implemented }\end{array}$ & 0.052 & 2 & 0.104 & 1 & 0.052 \\
\hline 26 & $\begin{array}{l}\text { Corporate governance assessments } \\
\text { have not been carried out routinely }\end{array}$ & 0.060 & 3 & 0.180 & 2 & 0.120 \\
\hline 27 & $\begin{array}{l}\text { The company's targets and } \\
\text { strategies have not been well } \\
\text { communicated to executive } \\
\text { employees }\end{array}$ & 0.049 & - & - & - & - \\
\hline 28 & $\begin{array}{l}\text { Sometimes project material } \\
\text { management does not go well }\end{array}$ & 0.069 & 2 & 0.138 & 3 & 0.207 \\
\hline 29 & $\begin{array}{l}\text { Corporate asset governance has not } \\
\text { been carried out in a structured } \\
\text { manner }\end{array}$ & 0.060 & 1 & 0.063 & 3 & 0.189 \\
\hline & Weighted Value & & & 4,787 & & 4,426 \\
\hline
\end{tabular}

\section{E. CONCLUSIONS AND SUGGESTIONS}

Following its objectives, this study produces four main results, namely (1) the EFE matrix, which contains eight opportunities and seven threats, and a weighted value of 2.93, which means that the good maintenance services business of Daya Minyak, Ltd can make good use of external opportunities and minimize potential. the detrimental impact of external threats ; (2) IFE matrix, which contains nine internal strengths and five weaknesses of the company, and a weighted value of 2.97 means that Daya Minyak, Ltd has good internal capabilities to support its business strategy; (3) From the position hold and maintain acquired two strategies, namely market penetration, and products development. Furthermore, with the TOWS matrix, details of the two strategies are obtained, namely: Increasing market penetration through integrated services with low operating costs, and developing products through increasing local material content with international standards; lastly (4) The strategic priority that will be carried out by Daya Minyak, Ltd for the period 2021-2024 is to increase market penetration through integrated services with low operating costs, followed by developing products through increasing local material content with international standards.

Advice is given over the suggestion to ensure the success of the implementation of the strategy had been developed, namely that the leadership of the company can deliver 2021-2024 strategic objectives to all executives and translate the strategic plan initiatives to become more operational, complete with size -the measure of its performance.

\section{REFERENCES}

Abbasi, F., Esparcia, J., dan Saadi, H. A. (2019). From Analysis to Formulation of Strategies for Farm Advisory Services: Valencia - Spain) - An Application Through SWOT and QSPM Matrix. European Countryside, 11(1), 43-73.

Ayoubi, M., Mehrabanfar, E., dan Banaitis, A. (2018). Guidelines on Designing Conceptual Framework for Strategic Management with Application to the Energy Industry. Administrative Sciences, 8(3)

Coman, A., dan Ronen, B. (2009). Focused SWOT: Diagnosing Critical Strengths and Weaknesses. International Journal of Production Research, 47(20), 5677 
Dahiri (2020). Analisis RUU tentang APBN No 06/an.PKA/APBN/ IX/2020 Harga Minyak dan Komoditas Unggulan Indonesia: Perkembangan dan Determinannya. Pusat Kajian Anggaran Badan Keahlian Dewan Perwakilan

David, F., dan David, F. (2016). Strategic Management: A Competitive Approach, Concepts, and Cases $16^{\text {th }}$ edition. New Jersey: Pearson

Denzin, N.K. dan Lincoln, Y.S. (2018). The Sage Handbook of Qualitative Research $5^{\text {th }}$ edition. Los Angeles : Sage

Fattouh, B., Poudineh, R., dan West, R. (2018). The Rise of Renewables and Energy Transition: What Adaptation Strategy for Oil Companies and Oil-Exporting Countries? Oxford Institute for Energy Studies diunduh dari https://ora.ox.ac.uk/objects/uuid:c4bee7fd-305f-4ec9-a681-6f46fb6ec07e

Helms, M. M., dan Nixon, J. (2010). Exploring SWOT Analysis - Where Are We Now?: A Review of Academic Research From the Last Decade. Journal of Strategy and Management, 3(3), 215-251.

Pazouki, M., Jozi, S. A., dan Ziari, Y. A. (2017). Strategic Management In Urban Environment Using SWOT and QSPM Model. Global Journal of Environmental Science and Management, 3(2), 207-216

Porter, M. (1998). Competitive Strategy: Techniques for Analyzing Industries and Competitors. New York: Free Press.

Realisasi investasi migas meleset dari target, Downloaded from https://www.skkmigas.go.id/news

Sekaran, U., dan Bougie, R. (2016). Research Methods For Business: A Skill Building Approach $7^{\text {th }}$ Edition. West Sussex: John Wiley dan Sons.

Serfointein, E., dan Govender, K. K. (2020). Stakeholders' Views Regarding MacroEnvironment Impacts on Commercial Flight Operations in South Africa. Journal of Transport and Supply Chain Management, 14

Singh, S., dan Srivastava, S. (2019). External Factors Affecting Indian Hand Loom Industry: A Paradigm Shift. International Journal of Business Insights and Transformation, 12(1), 33-41.

Slintak, K., dan Dvorsky, J. (2019). The Purpose of Firms and Its Influence on Formulating Their Missions and Visions. Montenegrin Journal of Economics, 15(2), 15-29.

Tonysheva, L.L., Yakunina, O.G., dan Yakunin, D.E. (2019). Modelling Oilfield Service Companies' Strategic Development: The Matrix. Espacios, 40(30), 17-25.

Vlados, C. (2019). On a Correlative and Evolutionary SWOT Analysis. Journal of Strategy and Management, 12(3), 347-363. 